\title{
Impacto da voz na qualidade de vida de professore(a)s do ensino fundamental $* * *$
}

\author{
The impact of voice on the quality of life of elementary school \\ teachers
}

\author{
Maria Helena Marotti Martelletti Grillo* (mhgrillo@terra.com.br) \\ Regina Zanella Penteado**
}

*Fonoaudióloga. Mestre pelo Programa de Pós-Graduação em Educação da Universidade Federal de São Carlos. Docente dos Cursos de

Fonoaudiologia, Direito e Letras da Universidade de Ribeirão Preto.

**Fonoaudióloga. Doutora em Saúde Pública pela Faculdade de Saúde Pública da Universidade de São Paulo. Docente dos Cursos de Mestrado, Especialização e Graduação em Fonoaudiologia da Universidade Metodista de Piracicaba.

***Trabalho Realizado na Universidade de Ribeirão Preto e na Universidade Metodista de Piracicaba.

Artigo de Pesquisa

Artigo Submetido a Avaliação por Pares

Conflito de Interesse: não

Recebido em 13.10.2004.

Revisado em 28.02.2005; 17.06.2005; 30.09.2005; 31.10.2005.

Aceito para Publicação em 31.10.2005.

\section{Abstract}

Background: relationship between voice and quality of life. Aim: to assess the impact of voice on the quality of life of elementary public school teachers. Method: application of the Voice-related quality of life questionnaire (VRQOL) with 120 teachers. The analysis involves: calculation of the Global Score (questions 1 to 10); descriptive analysis of the questions; calculation of Spearman's correlation coefficient between the Global Score, the question "how do you evaluate your voice?", age, teaching career (period of time) and teaching schedule. Results: the average Global Score of the VRQOL was 84.2. Most of the teachers $(49.2 \%)$ considered their voice as good, although they face difficulties when speaking, especially when having to speak louder in noisy environments. They also run out of breath quickly, having to breathe constantly while speaking (questions 1 and 2, respectively). The isolated question presented a significant linear correlation with all the other questions of the VRQOL, whereas age and teaching schedule did not present a significant correlation with any of the questions. Teaching career presented correlation with questions 2 and 5, regarding lack of breath and depression respectively. Based on the results, the impact of voice on the quality of life becomes evident when considering the use of voice at high intensities, coordination between breathing and speaking in the work environment and in the negative feelings, which are directly related to the vocal needs of these professionals. Conclusion: the impact of voice in the quality of life and work is still fairly noticed by teachers who demonstrate to have vocal needs. These vocal needs require health promotion actions which take into consideration the relationship between voice and the quality of life of teachers.

Key Words: Speech; Language and Hearing Sciences; Voice; Quality of Life; Teacher.

\section{Resumo}

Tema: relação voz e qualidade de vida. Objetivo: avaliar o impacto da voz na qualidade de vida de professores do Ensino Fundamental de escolas públicas. Método: aplicação do questionário protocolo de Qualidade de Vida e Voz (QVV) em 120 professores. A análise engloba o cálculo do Domínio Global (questões de 1 a 10), a análise descritiva das questões e o cálculo dos coeficientes de correlação de Spearman entre o Domínio Global, a questão "como avalia a sua voz", a idade, o tempo de magistério e a carga horária de trabalho. Resultados: a média do Domínio Global é 84,2 a maioria (49,2\%) avaliou a voz como boa, apesar de enfrentarem dificuldades ao falar, especialmente quando se trata de falar forte em ambientes ruidosos e do ar acabar rápido e precisar respirar muitas vezes enquanto fala (questões 1 e 2 , respectivamente). A questão isolada apresentou correlação linear significativa com todas as questões do QVV, ao passo que idade e carga horária não apresentaram correlação significativa com nenhuma das questões. Tempo de magistério apresentou correlação com as questões 2 e 5, relacionadas a problemas como falta de ar e depressão, respectivamente. O impacto da voz na qualidade de vida evidencia-se, portanto, no uso da voz em forte intensidade, na incoordenação pneumofônica, no trabalho e nos sentimentos negativos, diretamente relacionados às necessidades vocais da categoria. Conclusão: o impacto da voz sobre a qualidade de vida e trabalho é ainda pouco percebido pelos professores, que têm necessidades vocais que demandam ações de promoção da saúde que levem em conta a relação entre voz e qualidade de vida do professor.

Palavras-Chave: Fonoaudiologia; Voz; Qualidade de Vida; Docente. 


\section{Introduction}

The voice is present in the human socializing processes as one of the components of oral language and of interpersonal relationship, producing impacts on the quality of life of those who use spoken and/or singing voice in their work (Penteado and Bicudo-Pereira, 2003).

In the teaching profession, the voice is a relevant factor for the professional performance and for the teacher's behavior in the classroom, specially while as a component that constitutes the teacher's identity as a worker, for the impact of the teacher on the student and as a component of the teaching-learning process (Penteado, 2003; Penteado and Bicudo-Pereira, 2003; Grillo, 2004).

In the speech-language actions regarding the teacher's vocal health, it's necessary to broaden the perception and the analysis of the teacher's vocal health-disease process determinants, displacing the pathology/treatment axis for the health/promotion and incorporating the daily aspects and the life quality aspects that are related

\section{Method}

The research involved 120 teachers of State and City Elementary Schools from Ribeirão Preto's region.

This study is linked to the research "Quality of life and subjectivity aspects on teachers' vocal health promotion" from Penteado (2003), and the Research Ethics Committee of the Public Health Faculty of the University of São Paulo analyzed and approved, in 13/11/2001, its Research Protocol n ${ }^{\circ}$ 588. All participants agreed to participate in this research, reading and signing the Informed Consent Term.

The method consisted on applying the QVV (Life Quality and Vice Protocol) with the teachers. Such questionnaire refers to the adaptation and translation to the Portuguese language of the VRQOL instrument (Voice-related Quality of Life Measure), developed by Hogikyan and Sethuraman (1999). The QVV has been used in several speech-language researches for the investigation of the relations between quality of life and voice in teachers and subjects with or without vocal disorders, and it has been pointed out as an important instrument to evaluate the impact of dysphonia on speech-language patients' lives; to to the voice and to the vocal health (Penteado, 2003; Grillo, 2004).

Accordingly, researches that aim at investigating and relating the vocal health to life quality contribute, since they help to understand the subjects from their subjective experiences and from their perception and satisfaction regarding their own health and existence condition, taking into account the relational, the social, the working, the historical and the subjective aspects that interfere in the vocal production on several spaces and social relations associated with daily life. Some speech-language studies already point to this direction, focusing the quality of life related to the noise (Penteado and Bicudo-Pereira, 1999; Murry and Rosen, 2000; Vilkman, 2000; Behlau et al., 2001; Ma and Yiu, 2001; Serrano and Ferreira, 2002; Murry et al., 2004; Guimarães and Abberton, 2004).

The purpose of this article is to assess the impact of voice on the quality of life of public elementary schools' teachers. evaluate the subjects perception skill concerning the voice impact on his quality of life; to follow up the clinical treatment evolution and to support the action planning for teacher's vocal health promotion. (Behlau et al., 2001; Penteado and Bicudo-Pereira, 2003).

The QVV involves only 10 items and one isolated question (how do you evaluate your voice) and relates the quality of life and the voice, involving the Physical domain (questions 1, 2, 3, 6, 7 and 9), the Socio-Emotional domain $(4,5,8$ and 10) and the Global domain (questions from 1 to 10). This research uses the QVV Global domain calculation (involving all questions) since it has been evaluated in recent researches as the most interesting and reliable domain (Penteado and Bicudo-Pereira, 2003).

The QVV was applied in the subjects by the first researcher (Grillo) during a teachers' meeting from State and City Elementary Schools of Ribeirão Preto and whereabouts.

For a standard Global domain calculation, the following expression was used, proposed in the literature (Hogikyan and Sethuraman, 1999; Behlau et al., 2001):

$100-\underline{Q} .1+\mathrm{Q} .2+\mathrm{Q} .3+\mathrm{Q} .4+\mathrm{Q} .5+\mathrm{Q} .6+\mathrm{Q} .7+\mathrm{Q} .8+\mathrm{Q} .9+\mathrm{Q} .10-10) \times 100$ 
The Global domain presents varying values between 0 and 100; the worse values are closer to 0 and the better ones are closer to 100. A subject with a value of 50 for a certain domain can be considered median for this domain:

Regarding the statistical method used, firstly a general description of the sample was conducted through a descriptive analysis of the questions using frequency tables and frequency classes, according to the nature of the variable, respectively qualitative or quantitative. Results were illustrated in bar graphs.

Next, the correlation coefficient between the variables of interest was calculated. In cases of variables measured by scores, the studied literature suggests that it's better to choose the Spearman's coefficient correlation, which is a non-parametric, instead of the Pearsnon's coefficient correlation (Spiegel, 1993).

\section{Results}

Table 1 shows the sample's description for gender, age, teaching career time and time schedule.

It can be verified in Table 1 , the feminine prevalence in this Professional category, since there were only seven male teachers. The age of the subjects varied from 31 to 40 years old and the most frequent classes were from 31 to 40 years $(33,3 \%)$ and from 41 to 50 years $(31,7 \%)$.

The mean career time was 12,7 years, varying from 1 to 45 years, and only 18 of them present a career time longer than 20 years. The weekly time schedule varied from 2 to 63 hours/week, with an average of 32,2 hours/week. Only $9,2 \%$ of the teachers work up to 20 hours/week, while $4,2 \%$ teach for more than 50 hours/week.

The results showed that the majority of the subjects have been a teacher for more than five years with a high weekly time schedule of professional voice use, and because the great majority are women, they are more willing for social roles and family house work responsibilities that, many times, it can configure a double work shift, doubling the voice use request in the day-by-day and the weight that this represents for vocal health.

Table 2 presents the descriptive analysis of the question in which the teacher evaluates his/her own voice.

It can be verified that $24 \%$ of the subjects evaluated their own voice as very good or excellent;
$49,2 \%$ as good, while $26,7 \%$ evaluated it as fair or poor. The results show that, in general, teachers are satisfied with their vocal quality. It is interesting to note that several teachers who considered their voice as good, very good or excellent faced difficulties when speaking, specially when it's necessary to speak loudly in noise environments and they run out of air and need to take frequent breaths when talking (aspects rose in questions 1 and 2 of QVV and related to the Professional voice use) - the results showed in Table 3 evidence that the percentage of subjects who considered these aspects $(\mathrm{Q} 1, \mathrm{Q} 2)$ as a moderate to bad problem is over $26,7 \%$, indicating a possible limitation of self vocal evaluation skill in daily activities. It can not be forgotten that the voice is only one of the elements present in a classroom context. In this case, for the voice to cause a negative impact on communication, it's necessary to present a severe degree of disorder. This may partially explain the teacher's difficulty in self-evaluation (Grillo, 2004).

Table 3 presents the descriptive analysis of the QVV questions with the answers (categories) and respective scores.

It can be noted that $30,0 \%$ of the subjects never have problems in speaking loudly or being heard in noisy situations (Question 1), while for $40 \%$ of them this aspect is considered a moderate to bad problem. The teaching situation involves, in general, the voice use in noisy situations, leading the teacher to increase his voice intensity by the competitive sound and the need to overcome the noisy environment (Pereira et al., 2000). The teaching practice requests vocal resistance for using the voice with loud intensity and good vocal projection, components of a vocal psychodynamics that suggests authority and reliability (Vilkman, 2000). Therefore, it requests pneumophonic coordination and the diaphragmatic-abdominal or costodiaphragmaticabdominal breathing development, complete or total, which is the mechanically most efficient one for the development of the professional voice (Behlau et al., 2001). Thus, the fact that $40 \%$ of the subjects face problems regarding loud intensity vocal use indicates the necessity of vocal development of this Professional category, representing a speech-language demand concerning the teacher's vocal health promotion and improvement. 
TABLE 1. Descriptive analysis for gender, age, teaching career and time schedule.

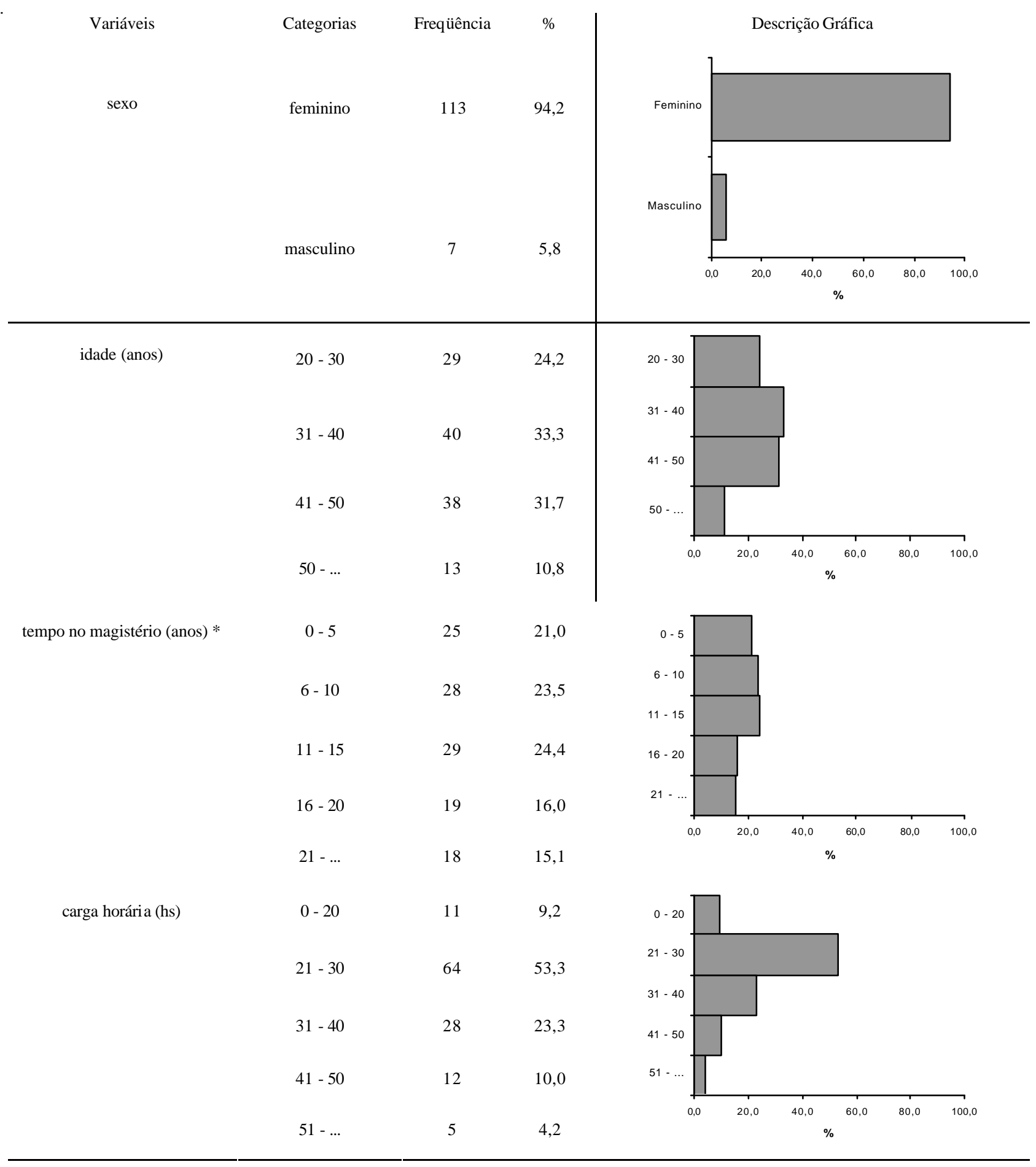

* Um dos professores não respondeu essa questão. 
In the second question, it can be verified that $33,0 \%$ of the teachers affirmed that they never run out of air nor need to take frequent breaths when talking; 30,8\% responded that this fact happens a little, and $35,8 \%$ affirmed that it is a moderate to bad problem. An utterance with adequate pneumophonic-articulatory coordination is a result of the harmonic inter-relation of the expiratory, the larynx myoelastic and the articulation muscle strengths in a balanced functional unit of all involved structures. The utterance with adequate pneumophonic-articulatory coordination is a necessity of the teacher's professional voice use, since it transmits to the listener the stability, control and harmony sensation; and the lack of pneumophonic coordination may generate compensations, such as the laryngeal hyperfunction leading to vocal stress, the same way it may affect the speech intelligibility (Behlau et al., 2001).

In the third question, $50 \%$ of the subjects responded that not knowing how the voice will come out when they start talking never happens, $30,8 \%$ affirmed that this aspect happens a little and that it rarely is a problem, while $19,2 \%$ considered this aspect as a moderate to bad problem. The results showed that, in general, Elementary School teachers do not face vocal quality instability and variability problems. However, the results analysis leads to another reflection perspective, towards considering the possibility that these teachers are not sensible enough for a self analysis of the vocal quality and of subtle variations of it. There are studies that show that the teacher presents difficulty to see himself as a voice professional, which could be an impeditive factor for his vocal self evaluation, once the voice does not constitute, for him, a working tool (Grillo et al., 2000).

Most of the subjects registered score 1 for questions from 4 to 10, indicating that Elementary School teachers don't get depressed, don't give in participating of social activities, nor alter their social behavior because of their voice/vocal health. These results confirmed those obtained by Penteado and Bicudo-Pereira (2003) in a research conducted with High School teachers that indicated little perception of subjects concerning the relation between voice and emotions/feelings and social relationships.

Nevertheless, despite $60,0 \%$ of the subjects having marked score 1 in question 7 , it can be observed that $20 \%$ of them face working problems because of the voice and considered that the problem varied from moderate to bad. The teacher is a voice professional who depends on it as a working tool and as a resource in the teacherstudent relationship and in the teaching-learning process (Dragone, 2001; Grillo, 2004). Therefore, the result that $20 \%$ of the subjects are facing working and profession-related problems due to their voice use can be confronted to the results of question 1 (that $40 \%$ have problems speaking loud or being heard in noisy situations) and to question 2 (that $35,8 \%$ have problems with the pneumophonic coordination), in order to discuss how the teachers, despite identifying some difficulties or problems regarding the voice use, still have difficulties in relating them to their work and in realizing their impact on the job (despite the voice being an important working resource for the teacher, the number of subjects who identified problems in its use was greater than those who recognized the voice impact on work/job).

TABLE 2. Descriptive analysis of the question: How do you evaluate your voice?

\begin{tabular}{|c|c|c|c|c|c|c|c|c|c|c|}
\hline Categorias & Escores & Freqüência & $\%$ & \multicolumn{7}{|c|}{ Descrição Gráfica } \\
\hline excelente & 1 & 8 & 6,6 & 1 & & & & & & \\
\hline muito boa & 2 & 21 & 17,5 & & & & & & & \\
\hline boa & 3 & 59 & 49,2 & 4 & & & & & & \\
\hline razoável & 4 & 29 & 24,2 & 5 & & & & & & \\
\hline & & & & 0,0 & 10,0 & 20,0 & 30,0 & 40,0 & 50,0 & 60,0 \\
\hline ruim & 5 & 3 & 2,5 & & & & $\%$ & & & \\
\hline
\end{tabular}


TABELA 3. Descriptive analysis of the Voice related Quality of life (QVV).

\begin{tabular}{|c|c|c|c|c|c|c|c|c|c|c|}
\hline Questões & Categorias & Escores & Freqüência & $\%$ & \multicolumn{6}{|c|}{ Descrição Gráfica } \\
\hline \multirow{5}{*}{$\begin{array}{l}\text { 1. Tenho dificuldades } \\
\text { em falar forte (alto) ou } \\
\text { ser ouvido em } \\
\text { ambientes ruidosos. }\end{array}$} & $\begin{array}{l}\text { nunca acontece e não é um } \\
\text { problema }\end{array}$ & 1 & 36 & 30,0 & 1 & & & & & \\
\hline & $\begin{array}{c}\text { acontece pouco e raramente é } \\
\text { um problema }\end{array}$ & 2 & 36 & 30,0 & 2 & & & & & \\
\hline & $\begin{array}{l}\text { acontece às vezes e é um } \\
\text { problema moderado }\end{array}$ & 3 & 29 & 24,2 & 3 & & & & & \\
\hline & $\begin{array}{c}\text { acontece muito e quase sempre } \\
\text { é um problema }\end{array}$ & 4 & 16 & 13,3 & 5 & & & & & \\
\hline & $\begin{array}{l}\text { acontece sempre e realmente é } \\
\text { problema ruim }\end{array}$ & 5 & 3 & 2,5 & 0,0 & 20,0 & & 60,0 & 80,0 & 100,0 \\
\hline \multirow{5}{*}{$\begin{array}{l}\text { 2. O ar acaba rápido e } \\
\text { preciso respirar muitas } \\
\text { vezes enquanto eu falo. }\end{array}$} & $\begin{array}{c}\text { nunca acontece e não é um } \\
\text { problema }\end{array}$ & 1 & 40 & 33,3 & 1 & & & & & \\
\hline & $\begin{array}{c}\text { acontece pouco e raramente é } \\
\text { um problema }\end{array}$ & 2 & 37 & 30,8 & 2 & & & & & \\
\hline & $\begin{array}{l}\text { acontece às vezes e é um } \\
\text { problema moderado }\end{array}$ & 3 & 31 & 25,8 & 3 & & & & & \\
\hline & $\begin{array}{l}\text { acontece muito e quase sempre } \\
\text { é um problema }\end{array}$ & 4 & 11 & 9,2 & 5 & & & & & \\
\hline & $\begin{array}{l}\text { acontece sempre e realmente é } \\
\text { problema ruim }\end{array}$ & 5 & 1 & 0,8 & 0,0 & 20,0 & 40,0 & 60,0 & 80,0 & 100,0 \\
\hline \multirow{5}{*}{$\begin{array}{l}\text { 3. Não sei como a voz } \\
\text { vai sair quando começo } \\
\text { a falar. }\end{array}$} & $\begin{array}{c}\text { nunca acontece e não é um } \\
\text { problema }\end{array}$ & 1 & 60 & 50,0 & 1 & & & & & \\
\hline & $\begin{array}{c}\text { acontece pouco e raramente é } \\
\text { um problema }\end{array}$ & 2 & 37 & 30,8 & 2 & & & & & \\
\hline & $\begin{array}{l}\text { acontece às vezes e é um } \\
\text { problema moderado }\end{array}$ & 3 & 14 & 11,7 & 3 & & & & & \\
\hline & $\begin{array}{c}\text { acontece muito e quase sempre } \\
\text { é um problema }\end{array}$ & 4 & 5 & 4,2 & 5 & & & & & \\
\hline & $\begin{array}{c}\text { acontece sempre e realmente é } \\
\text { problema ruim }\end{array}$ & 5 & 4 & 3,3 & 0,0 & 20, & 40,0 & 60,0 & 80,0 & 100,0 \\
\hline \multirow{5}{*}{$\begin{array}{l}\text { 4. Fico ansioso ou } \\
\text { frustrado (por causa da } \\
\text { minha voz). }\end{array}$} & $\begin{array}{c}\text { nunca acontece e não é um } \\
\text { problema }\end{array}$ & 1 & 81 & 67,5 & 1 & & & & & \\
\hline & $\begin{array}{c}\text { acontece pouco e raramente é } \\
\text { um problema }\end{array}$ & 2 & 18 & 15,0 & 2 & & & & & \\
\hline & $\begin{array}{l}\text { acontece às vezes e é um } \\
\text { problema moderado }\end{array}$ & 3 & 14 & 11,7 & 3 & & & & & \\
\hline & $\begin{array}{c}\text { acontece muito e quase sempre } \\
\text { é um problema }\end{array}$ & 4 & 3 & 2,5 & 5 & & & & & \\
\hline & $\begin{array}{c}\text { acontece sempre e realmente é } \\
\text { problema ruim }\end{array}$ & 5 & 4 & 3,3 & 0, & 20, & 40,0 & & 80,0 & 100,0 \\
\hline \multirow{5}{*}{$\begin{array}{l}\text { 5. Fico deprimido (por } \\
\text { causa da minha voz). }\end{array}$} & $\begin{array}{c}\text { nunca acontece e não é um } \\
\text { problema }\end{array}$ & 1 & 93 & 77,5 & 1 & & & & & \\
\hline & $\begin{array}{c}\text { acontece pouco e raramente é } \\
\text { um problema }\end{array}$ & 2 & 14 & 11,7 & 2 & & & & & \\
\hline & $\begin{array}{l}\text { acontece às vezes e é um } \\
\text { problema moderado }\end{array}$ & 3 & 9 & 7,5 & 4 & & & & & \\
\hline & $\begin{array}{c}\text { acontece muito e quase sempre } \\
\text { é um problema }\end{array}$ & 4 & 3 & 2,5 & 5 & & & & & \\
\hline & $\begin{array}{l}\text { acontece sempre e realmente é } \\
\text { problema ruim }\end{array}$ & 5 & 1 & 0,8 & 0,0 & 20, & 40,0 & & 80,0 & 100,0 \\
\hline
\end{tabular}


TABLE 3. Descriptive analysis of the Voice-related Quality of life (QVV). (continuation of Table 3).

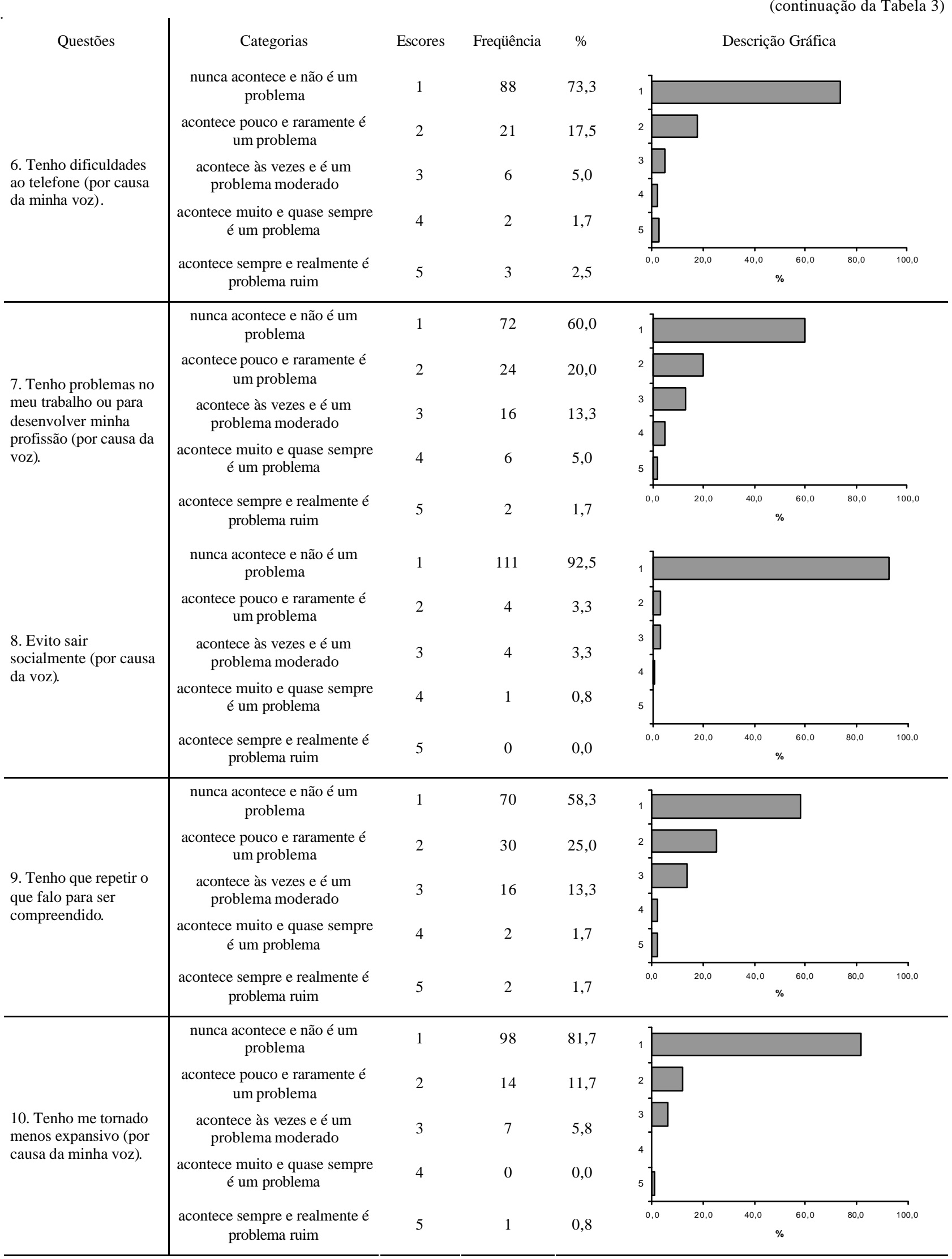


This indicates the importance of thinking the relation voice/teaching, as well as the necessity of the speech-language therapist to investigate efforts in organizing collective actions for vocal health promotion that consider such relation (Orlova et al., 2000; Grillo, 2004).

Considering that scores greater or equal to 3 represent some problem for the teacher, it can be evidenced that the most affected question was question 1 (405); followed by question $2(35,8 \%)$, $7(20,0 \%), 3(19,2 \%), 4(17,5 \%), 9(16,7 \%), 5(10,8 \%)$, $6(9,2 \%)$ and $10(6,6 \%)$, in this order, and the least affected one is question $8(4,1 \%$ registered scores greater or equal to 3 ), that is related to avoidance of social activities because of the voice.

Thus, it can be noted that the negative impact of voice on the quality of life of Elementary School teachers is directly related to the vocal needs of this professional category, that is, the impact is more evident on the aspects related to the voice use demand in noisy environments and with loud intensity, to the pneumophonic-articulatory coordination and to the vocal quality stability. In this sense, other authors such as Orlova et al. (2000), have already pointed out the teachers' difficulties related to the excessive voice use.

Figure 1 presents the histogram of the QVV Global Domain.

The score values of the global domain varied from 7,5 to 100 , with an average of 84,2 , which may be considered good. The global domain scores are centered on the most elevated values of the scale (between 80 and 1000), indicating that, in general, the teachers of the sample don't have problems with the voice impact on their quality of life (Figure 1). This leads us to reflect about the attention and perception skills of the teachers concerning their own voice and the daily use of it, as well as the impact that vocal health problems or alterations may have on their quality of life, even suggesting that they are being underestimated by this working category.

Table 4 shows the Spearman's correlation coefficient between the global domain of the Voicerelated Quality of Life (QVV) and the question "How do you evaluate your voice" with the question "How do you evaluate your voice", the age, the Teaching career, and the Time Schedule.

It's possible to observe that, except the correlation between "How do you evaluate your voice" and the QVV Global Domain, the other correlations were not significant $(p>0,05)$. Despite the correlation between "How do you evaluate your voice" and the QVV Global Domain being negative $(-0,692)$, it denotes that the worse the individual assesses his voice, the worse is the QVV Global Domain (the worse is the voice negative impact on the quality of life), once the responses' scores to the question "How do you evaluate your voice" are in inverse order. These results agree with studies performed with High School teachers who present the same type of correlation (Penteado and Bicudo-Pereira, 2003).

Table 5 shows the Spearman's correlation coefficients and the " $t$ " test for the crossing of the Voice-related Quality of Life (QVV) with the question "How do you evaluate your voice", the Age, the Teaching Career and the Time Schedule.

The question "How do you evaluate your voice" has also presented a significant linear correlation with all the QVV questions, agreeing with the results of similar studies performed with High School teachers (Penteado and BicudoPereira, 2003); the greatest correlations were with the questions $1(0,626), 3(0,562), 7(0,518)$ and 9 $(0,506)$, and the lowest correlation was with question $8(0,221)$, that is related to the avoiding going out socially because of the voice (Table 5).

FIGURE 1. Presents the histogram of the QVV Global Domain.

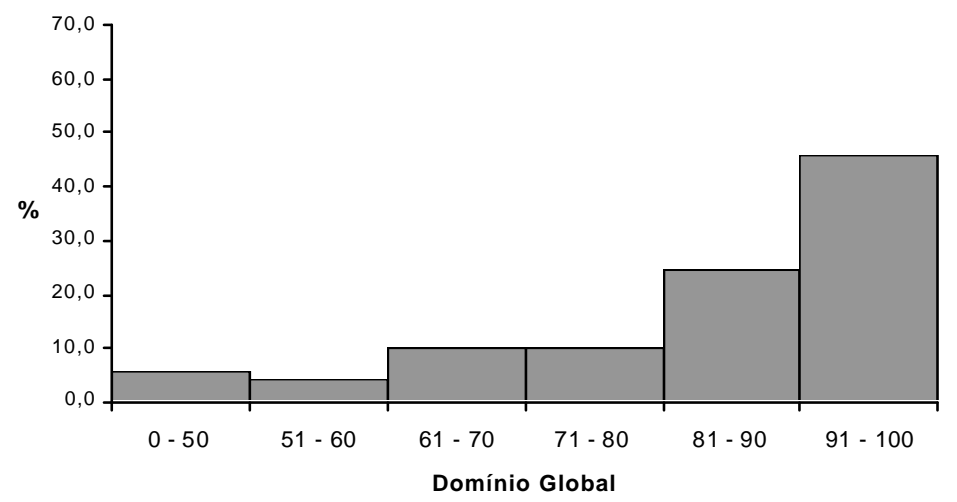

TABLE 4. Spearman's correlation coefficient and " $\mathrm{t}$ " test for the crossing between the QVV Global Domain and the question "How do you evaluate your voice" with the question "How do you evaluate your voice", the age, the Teaching career and the Time schedule.

\begin{tabular}{c|c|ccc} 
& $\begin{array}{c}\text { Como você } \\
\text { Avalia sua Voz }\end{array}$ & Idade & $\begin{array}{c}\text { Tempo de } \\
\text { Magistério }\end{array}$ & $\begin{array}{c}\text { Carga } \\
\text { Horária }\end{array}$ \\
$\begin{array}{c}\text { domínio global } \\
\text { do QVV }\end{array}$ & $-0,692^{* *}$ & $-0,032^{\text {ns }}$ & $0,170^{\mathrm{ns}}$ & $0,088^{\mathrm{ns}}$ \\
$\begin{array}{c}\text { como você } \\
\text { avalia sua voz }\end{array}$ & - & $0,020^{\mathrm{ns}}$ & $0,054^{\mathrm{ns}}$ & $-0,131^{\mathrm{ns}}$ \\
\hline
\end{tabular}

$\mathrm{ns}=$ Não significativo, pelo teste " $\mathrm{t}$ ", considerando-se um n. m. s. de $5 \%$ $(\mathrm{p}>0,05) ; * *=$ Significativo, pelo teste "t", ao nível de $1 \%(\mathrm{p} \leq 0,01)$. 
TABLE 5. Spearman's correlation coefficients and "t" test for the crossing between the QVV questions with the question "How do you evaluate your voice", the Age, the Teaching Career, and the Time Schedule.

\begin{tabular}{|c|c|c|c|c|}
\hline Questões & Como você avalia sua voz & Idade & Tempo de Magistério & Carga Horária \\
\hline 1 & $0,626 * *$ & $0,033^{\text {ns }}$ & $0,101^{\mathrm{ns}}$ & $-0,042^{\text {ns }}$ \\
\hline 2 & $0,431 * *$ & $-0,053^{\text {ns }}$ & $0,212 *$ & $-0,146^{\mathrm{ns}}$ \\
\hline 3 & $0,562 * *$ & $0,061^{\mathrm{ns}}$ & $0,130^{\mathrm{ns}}$ & $-0,047^{\mathrm{ns}}$ \\
\hline 4 & $0,491 * *$ & $-0,054^{\mathrm{ns}}$ & $0,093^{\mathrm{ns}}$ & $-0,046^{\mathrm{ns}}$ \\
\hline 5 & $0,408 * *$ & $0,131^{\text {ns }}$ & $0,217 *$ & $-0,036^{\mathrm{ns}}$ \\
\hline 6 & $0,466 * *$ & $0,067^{\text {ns }}$ & $0,099^{\mathrm{ns}}$ & $0,042^{\mathrm{ns}}$ \\
\hline 7 & $0,518 * *$ & $0,007^{\text {ns }}$ & $0,149^{\mathrm{ns}}$ & $-0,008^{\text {ns }}$ \\
\hline 8 & $0,221 *$ & $0,125^{\text {ns }}$ & $0,174^{\mathrm{ns}}$ & $-0,029^{\mathrm{ns}}$ \\
\hline 9 & $0,506 * *$ & $0,047^{\text {ns }}$ & $0,145^{\mathrm{ns}}$ & $0,036^{\mathrm{ns}}$ \\
\hline 10 & $0,374 * *$ & $0,112^{\text {ns }}$ & $0,145^{\mathrm{ns}}$ & $-0,164^{\mathrm{ns}}$ \\
\hline
\end{tabular}

$\mathrm{ns}=$ Não significativo, pelo teste "t", considerando-se um n. m. s. de 5\% (p >0,05);* = Significativo, pelo teste "t", ao nível de 5\% $(\mathrm{p} \leq 0,05) ; * *=$ Significativo, pelo teste "t”, ao nível de $1 \%(\mathrm{p} \leq 0,01)$.

The Age and the Time Schedule didn't present significant correlation with none of the $10 \mathrm{QVV}$ questions, while the Teaching Career time presented significant correlation with questions 2 and 5. The interpretation of those correlations shows that the longer the teaching career is, the more the teachers run out of air (question 2) and get depressed because of the voice (question 5). Ramig and Verdolini (1998) and Orlova et al (2000) affirmed that vocal disorders cause psycho-emotional stress, depression and frustration affecting negatively the social functioning and causing a significant impact $n$ the quality and efficiency of work. It seems to us that the longer the teaching career is, the higher are the chances of having problems related with the voice use and the vocal and general health of the teacher.

This indicates that the speech-language action for the vocal health promotion must initiate by the teacher's formation and be extended through his career, integrating the continued formation proposal and the health promotion of those workers.

\section{Conclusions}

The mean score of QVV Global Domain was 84,2 and the majority of the subjects evaluated their voice as good, which demonstrates that, in general, the teachers are satisfied with their quality of life.

Despite that, the descriptive analysis of the questions evidenced that voice use related needs and problems have a negative impact on the teacher's quality of life. The main needs and problems are noticed in daily life situations related to the professional development and teaching such as those that require the use of a loud intensity in noisy environments (such as classrooms, meeting rooms), and those that demand adequate pneumophonic coordination - besides the situations involving subjective aspects (such as emotions and negative feelings of the subjects regarding their own voice).

The confrontation of the favorable results obtained by the mean score of the QVV Global Domain and by the self-satisfaction with the own voice, with those of the descriptive analysis of the questions that indicate impact on the teacher's quality of life, shows the importance of searching to know the teachers' representations of their own voice, of its Professional use and of the healthdisease process related to it, so that these data may support future vocal health education actions aiming at contributing for the teachers' voice/vocal health attention and appreciation.

The prevalence of women within the Elementary School teachers indicates that gender-related questions can not be disregarded when thinking about speech-language actions for the teachers' vocal and general health promotion that should consider the quality of life, once they are more exposed to the working responsibilities and demands resultant from the accumulation of social roles in the working and familiar environments. 
The relation between the increasing teaching career time and the worse QVV scores shows that the more years dedicated to the profession, the higher the chances of developing voice use problems and vocal and general health affections, even though researches do not confirm the relation between vocal complaint and teaching career time.

\section{References}

BEHLAU, M.; MADÁZIO, G.; FEIJÓ, D.; PONTES, P. Avaliação de voz. In: BEHLAU, M. (Org.). Voz: o livro do especialista. Revinter, Rio de Janeiro, 2001. v. 1, cap. 3, p. $85-246$.

DRAGONE, M. L. O. S. Novos caminhos para os estudos sobre a voz do professor. Rev. Fonoaudiologia Brasil, Brasília, v. 1, n. 1, p. 43-50, set. 2001.

GRILLO, M. H. M. M. The impact of a vocal improvement course in a speech language and hearing science prevention context. Pró-Fono Revista de Atualização Científica, Barueri (SP), v. 16, n. 2, p. 159-168, maio-ago. 2004.

GRILLO, M. H. M. M.; LIMA, E. F.; FERREIRA, L. P. A questão ensino-aprendizagem num trabalho profilático de aperfeiçoamento vocal com professores. Pró-Fono Revista de Atualização Científica, Barueri (SP), v. 12, n. 2, p. 73-80, set. 2000.

GUIMARÃES, I.; ABBERTON, E. An investigation of the voice handicap index with speakers of portuguese: preliminary data. J. Voice, New York, v. 18, n. 1, p. 71-82, mar. 2004.

HOGIKYAN, N. D.; SETHURAMAN, G. Validation of an instrument to measure Voice-Related Quality of Life (VRQOL). J. Voice, New York, v. 13, n. 4, p. 557-569, apr. 1999.

MA, E. P.; YIU, E. M. Voice activity and participation profile: assessing the impact of voice disorders on daily activities. J. Speech Lang. Hear. Res., Rockville, 44, n. 3, p. 511-524, jun. 2001.

MURRY, T.; MEDRADO, T.; HOGIKYAN, N.; AVIV, J. The relationship between ratings of voice quality and quality of life measures. J. Voice, v. 18, n. 2, p. 183-192, jun. 2004.

MURRY T.; ROSEN C. A. Outcome measurements and quality of life in voice disorders. Otolaryngol. Clin. North Am., v. 33, n. 4 p. $905-916$, oct. 2000.
It can be concluded that since teaching is a job involving gender matters and that it has specific demands and needs related to the professional voice use for long periods and in critical working conditions that are repeated over the years, the speech-language action for the vocal health promotion should begin from the teachers' formation and continue throughout his career, integrating the proposals of continued formation and health promotion of these workers.

ORLOVA, O. S.; VASILENKO, I. S.; ZAKHAROVA, A. F.; SAMOKHVALOVA, L. O.; KOZLOVA. P. A. The prevalence, causes and specific features of voice disturbances in teachers. Vestn. Otorrinolaringol., n. 5, p. 18-21, 2000.

PENTEADO, R. Z. Aspectos de qualidade de vida e de subjetividade na promoção da saúde vocal do professor. 2003. 219 f. Tese (Doutorado) - Faculdade de Saúde Pública da Universidade de São Paulo, São Paulo.

PENTEADO, R. Z.; BICUDO-PEREIRA, I. M. T. A voz do professor: relações entre trabalho, saúde e qualidade de vida. Rev. Bras. Saúde Ocupacional, São Paulo, n. 95/96, v. 25, p. 109-130, abr. 1999.

PENTEADO, R. Z.; BICUDO-PEREIRA, I. M. T. Avaliação do impacto da voz na qualidade de vida de professores. Rev. Soc. Bras. de Fonoaudiologia, São Paulo, ano 8 n. 2, p. 19-28, dez. 2003.

PEREIRA, M. J.; SANTOS, T. M. M.; VIOLA, I. C. Influência do nível de ruído em sala de aula sobre a performance vocal do professor. In: FERREIRA, L. P.; COSTA, H. O. Voz ativa: falando sobre o profissional da voz. São Paulo: Roca, 2000. cap. 4, p. 57-65.

RAMIG, L.; VERDOLINI, K. Treatment efficacy: voice disorders. J. Speech Lang. Hear. Res., Rockville, v. 41, n. 1, p. 101-106, 1998.

SERRANO, D. A. C.; FERREIRA, L. P. Qualidade de vida x impacto da disfonia no dia-a-dia de operadores de telemarketing. Rev. Soc. Bras. Fonoaudiologia, São Paulo, ano 7, n. 2, p. 43-52, dez. 2002.

SPIEGEL, M. R. Estatística. 3. ed. São Paulo: Makron Books, 1993.

VILKMAN, E. Voice problems at work: a challenge for occupational safety and health arrangement. Folia Phoniatr. Logop., v. 1-3, n. 52, p. 120-125, jan.-jun. 2000. 